\title{
IN VITRO CYTOLYSIS OF MM46 TUMOR CELLS BY MOUSE PHAGOCYTES ACTIVATED BY ACIDIC MANNAN FRACTION OF BAKERS' YEAST
}

\author{
Kazuhiko Hashimoto, ${ }^{*}$ Yoshio OKawa, ${ }^{*}$ Takeshi Mikami, ${ }^{*}$ Shigeo SuzUki** and \\ MASUKO SUZUKI*
}

Department of Microbiology* and Second Department of Hygienic Chemistry,** Tohoku College of Pharmacy, Komatsushima 4-4-1, Sendai-shi, Miyagi, 983, Japan

(Received January 5, 1984)

An acidic mannan from bakers' yeast designated as WAM025 was investigated for its augmentative effect on cytolytic activity of phagocytes obtained from the peritoneal cavity of $\mathrm{C} 3 \mathrm{H} / \mathrm{He}$ strain mice, which had been administered i.p. with this acidic polysaccharide, 150 $\mathrm{mg} / \mathrm{kg} / \mathrm{d}, 5$ and 10 times.

The result of assay for the cytolytic effect of WAM025-activated phagocytes by measuring the amounts of ${ }^{3} \mathrm{H}$-uridine of the MM46 tumor cells indicated that a marked lysis of the target cells took place by a 24-h incubation with the activated phagocytes and that a decrease of this effect was observed by the additions of either phagocytic inhibitors or active oxygen scavengers.

Because generation of active oxygens from the WAM025-activated phagocytes was also diminished by the additions of the same inhibitors and scavengers, it indicated that active oxygens participated in an important role in the cytolytic effect displayed by the WAM025activated phagocytes.

Keywords - acidic mannan; activated phagocyte; syngeneic tumor cell; cytolytic effect; active oxygen

\section{INTRODUCTION}

In the preceding paper, ${ }^{1)}$ we demonstrated that the acidic fraction of bakers' yeast mannan (a wild type strain of Saccharomyces cerevisiae) abbreviated as WAM025 was able to display a marked antitumor effect to ascites forms of syngeneic and allogeneic tumors implanted in mice. The above finding led us to an assumpiton that the WAM025-activated phagocytes or lymphocytes might participate in a large part of the antitumor activity of this acidic polysaccharide.

It has also been reported in the preceding paper $^{1)}$ that a significant increase of number of polymorphonuclear leukocytes (PMNs) and macrophages was observed in mice when this acidic mannan was administered via i.p. route, and that elevation of the levels of lysosomal enzymes and of the amount of released active oxygens in the same PMN and macrophage speci- mens was also evident.

In order to provide the direct evidence for the clarification of the mechanism of antitumor effect of WAM025, ${ }^{1)}$ we conducted an in vitro tumor cell-injuring assay by mouse phagocytes treated with WAM025 in vivo, using MM46 tumor cells as the target cells.

\section{MATERIALS AND METHODS}

Mice - Male $\mathrm{C} 3 \mathrm{H} / \mathrm{He}$ mice, supplied by Shizuoka Experimental Animal Corp., Shizuoka, from 6 to 8 weeks old, were used.

Tumor - MM46 tumor cells were donated by Dr. T. Tachibana, Research Institute for Tuberculosis and Cancer, Tohoku University. The tumor cells were maintained continuously in ascites form of $\mathrm{C} 3 \mathrm{H} / \mathrm{He}$ mice in our laboratory.

Preparation of Mannan Fraction, WAM025 - The mannan of bakers' yeast was prepared in 
accordance with the description of the previous paper. ${ }^{1)}$

Preparation of Phagocytes - The peritoneal exudate cells (PECs) were collected from the peritoneal cavity of mice administered with WAM025 in a dose of $150 \mathrm{mg} / \mathrm{kg} / \mathrm{d}, 5$ and 10 times. The PECs were incubated at $37^{\circ} \mathrm{C}$ for $2 \mathrm{~h}$ under $5 \% \mathrm{CO}_{2}$ in air. To obtain phagocytes, nonadherent cells of PECs were removed by washing with RPMI 1640 medium containing 10\% fetal bovine serum (FBS). PECs contained macrophages, polymorphonuclear leukocytes (PMNs) and lymphocytes, and peritoneal phagocytes consisted of macrophages and PMNs, which were distinguished by May-Giemsa stain.

Reagents - Colchicine, cytochalasin B, cytochrome C (Type III), superoxide dismutase (Type I), and catalase were purchased from Nakarai Chemical Co., Ltd., Kyoto, Japan. Phorbol myristate acetate (PMA) was purchased from Sigma Chemical Co., U.S.A.

Cytolytic Assay — Assay of cytolysis was conducted according to the method of Hashimoto et al. ${ }^{2)}$ That is, one volume of a solution of ${ }^{3} \mathrm{H}$ uridine in physiological saline was added to the cell suspension containing $1 \times 10^{7}$ of MM46 tumor cells to make $0.5 \mu \mathrm{Ci} / \mathrm{ml}$. After incubation for $24 \mathrm{~h}$, the cells were sedimented by centrifugation at $250 \times \boldsymbol{g}$ for $10 \mathrm{~min}$, and then washed 3 times with the RPMI 1640 medium containing $10 \%$ FBS. The peritoneal phagocytes $(0.5,1$, and 2 $\times 10^{6}$ cells $)$ and the target cells $\left(1 \times 10^{4}\right.$ cells $)$ were mixed in wells ( $7 \mathrm{~mm}$ diameter) of a roundbottomed microplate (Nunc, Roskilde, Denmark). The mixture was incubated in $0.2 \mathrm{ml}$ of RPMI 1640 medium containing 10\% FBS for 24 $\mathrm{h}$ at $37^{\circ} \mathrm{C}$ under $5 \% \mathrm{CO}_{2}$ in air. The cells were harvested on glass filter papers, and counted by means of a Beckman LS-7800 liquid scintillation counter.

Chemiluminescence Assay - Chemiluminescence responses were measured by the method in accordance with the description of the previous paper. ${ }^{1)}$

Inhibition of Cytolytic Activity of Phagocytes by Phagocytic Inhibitors or by Active Oxygen Scaven- gers - To a peritoneal phagocytes $\left(2 \times 10^{6}\right.$ cells) in wells ( $7 \mathrm{~mm}$ diameter) of a round-bottomed microplate (Nunc, Roskilde, Denmark) was added $0.1 \mathrm{ml}$ of RPMI 1640 medium containing $10 \%$ FBS of each inhibitor or scavenger. Then a suspension of ${ }^{3} \mathrm{H}$-uridine-incorporated MM46 cells $\left(1 \times 10^{4}\right.$ cells $)$ in $0.1 \mathrm{ml}$ of RPMI 1640 medium containing 10\% FBS was added, and the mixture was incubated at $37^{\circ} \mathrm{C}$ for $24 \mathrm{~h}$ under $5 \% \mathrm{CO}_{2}$ in air. The cells were harvested and the radioactivity was counted by exactly the same method as that described in Cytolytic Assay.

Inhibition of Chemiluminescence Response by Phagocytic Inhibitors or by Active Oxygen Scavengers - This was conducted in accordance with the descriptions by Curnutte et al. ${ }^{3)}$ and Nathan et $a l^{4)}$ as follows: Each inhibitor or scavenger was dissolved in Krebs Ringer phosphate buffer (KRPB), pH 7.2 or in dimethyl sulfoxide. Concentrations of the solutions of colchicine, cytochalasin $\mathrm{B}$, cytochrome $\mathrm{C}$, superoxide dismutase, and catalase were $4 \mathrm{mg} / \mathrm{ml}, 0.1 \mathrm{mg} / \mathrm{ml}, 13$ $\mathrm{mg} / \mathrm{ml}, 2400$ and $4800 \mathrm{U} / \mathrm{ml}$, and 2400 and 4800 $\mathrm{U} / \mathrm{ml}$, respectively. Mice were administered with WAM025 in a dose of $150 \mathrm{mg} / \mathrm{kg} / \mathrm{d}, 5$ times. PECs were collected on day 6 . The cells were collected by adhering to cover slips and nonadherent cells were removed by washing with RPMI 1640 medium containing 10\% FBS. Two cover slips attached with $2-3 \times 10^{6}$ phagocytes were carefully placed on the bottom of a cuvette of chemiluminescence photometer containing 1.5 $\mathrm{ml}$ of KRPB, pH 7.2 and the mixture incubated at $37^{\circ} \mathrm{C}$ for $10 \mathrm{~min}$. To the mixture was added 0.1 $\mathrm{ml}$ of KRPB, $\mathrm{pH} 7.2$, solution of each inhibitor or scavenger. After addition of $10 \mu \mathrm{l}$ of dimethyl sulfoxide solution of PMA $(1 \mu \mathrm{g} / \mathrm{ml})$, the extent of chemiluminescence response was determined for $10 \mathrm{~min}$. Measurement of chemiluminescence response of the incubation mixtures containing colchicine and cytochalasin B was made after a 1 - $h$ incubation and the subsequent addition of PMA solution.

RESULTS

Population of PECs Obtained from WAM025- 


\section{Administered Mice}

Fig. 1 shows the population of PECs in mice administered with WAM025 in a dose of 150 $\mathrm{mg} / \mathrm{kg} / \mathrm{d}, 5$ and 10 times. The cells were distinguished by using May-Giemsa stain. The number of PECs in mice administered with WAM025 i.p. in a dose of $150 \mathrm{mg} / \mathrm{kg} / \mathrm{d}, 5$ and 10 times, increased to 8 and 13 folds, respectively, as compared with that of PECs of control mice. The ratios of PMNs in PECs of mice administered with WAM025 in a dose of $150 \mathrm{mg} / \mathrm{kg} / \mathrm{d}, 5$ and 10 times, were about 40 and $20 \%$ respectively, demonstrating a decreasing tendency. On the contrary, the proportion of macrophages increased markedly from 50 to $70 \%$, but the number of lymphocytes did not change significantly.

Cytolytic Effect of Peritoneal Phagocytes Obtained from WAM025-Administered Mice to MM46 Tumor Cells

Fig. 2 shows cytolysis of peritoneal phagocytes with or without lymphocytes, which were

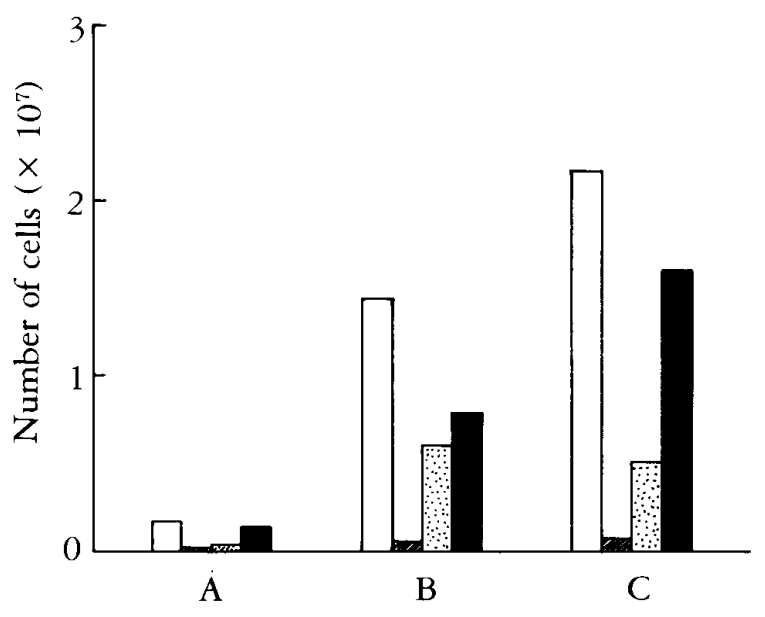

FIG. 1. Population of Peritoneal Exudate Cells in Mice Administered with Acidic Mannan, WAM025

The mice were administered i.p. with the mannan for 5 and $10 \mathrm{~d}$. PECs were collected on day 6 and 11, and population of PECs was determined by May-Giemsa stain.

$\square$ : PECs, $\square$ : lymphocytes, $:$ : PMNs, $\mathbf{0}$ : macrophages, A: control, B: WAM025, $150 \mathrm{mg}$ / $\mathrm{kg} / \mathrm{d} \times 5, C: W A M 025,150 \mathrm{mg} / \mathrm{kg} / \mathrm{d} \times 10$. obtained from mice administered with WAM025 in a dose of $150 \mathrm{mg} / \mathrm{kg} / \mathrm{d}, 5$ and 10 times. As can be pointed out, significant difference was not

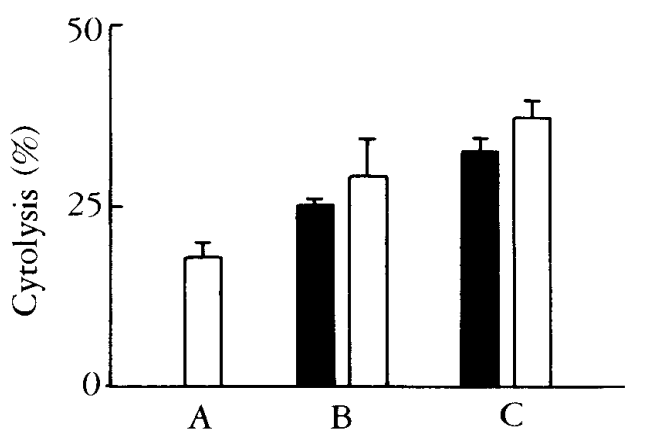

FIG. 2. Cytolysis by Peritoneal Phagocytes in Mice Administered with Acidic Mannan, WAM025

The mice were administered i.p. with the mannan for 5 and $10 \mathrm{~d}$. PECs were collected on day 6 and 11. Nonadherent cells were removed by washing with medium. Cytolysis was performed at $37^{\circ} \mathrm{C}$ for $24 \mathrm{~h}$ in $5 \% \mathrm{CO}_{2}$ incubator. Ratio of number of the effector cells to the tumor cells was 200:1.

: peritoneal phagocytes, $\square:$ PECs, A: control, B: WAM025, $150 \mathrm{mg} / \mathrm{kg} / \mathrm{d} \times 5, C:$ WAM025, $150 \mathrm{mg} / \mathrm{kg} / \mathrm{d} \times 10$.

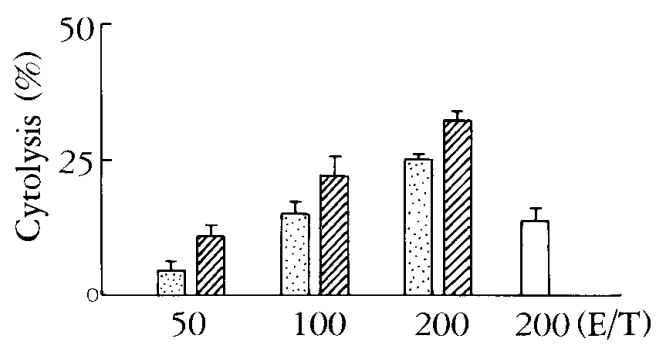

FIG. 3. Cytolysis Depended on Number of Peritoneal Phagocytes in Mice Administered with Acidic Mannan, WAM025

The mice were administered i.p. with the mannan for 5 and $10 \mathrm{~d}$. Peritoneal Phagocytes were prepared on day 6 and 11.

Cytolysis was performed at $37^{\circ} \mathrm{C}$ for $24 \mathrm{~h}$ in $5 \%$ $\mathrm{CO}_{2}$ incubator. Ratio of number of the effector cells to the tumor cells was $50: 1,100: 1$ and $200: 1$, respectively.

$\square$ : untreated phagocytes, $\square:$ WAM025treated phagocytes, $150 \mathrm{mg} / \mathrm{kg} / \mathrm{d} \times 5$, $\square:$ WAM025-treated phagocytes, $150 \mathrm{mg} / \mathrm{kg} / \mathrm{d} \times 10$. 
TABle I. Inhibition to Cytolytic Effect by Peritoneal Phagocytes in Mice Administered with Acidic Mannan, WAM025

\begin{tabular}{lcc}
\hline \hline \multicolumn{1}{c}{ Reagent } & Concentration & Inhibition (\%) \\
\hline Colchicine & $3 \mathrm{mM}$ & 62 \\
Cytochalasin B & $65 \mu \mathrm{M}$ & 73 \\
Cytochrome C & $130 \mu \mathrm{M}$ & 87 \\
Superoxide dismutase & $1500 \mathrm{U} / \mathrm{ml}$ & 33 \\
Catalase & $1500 \mathrm{U} / \mathrm{ml}$ & 37 \\
\hline
\end{tabular}

PECS were collected on day 11. Nonadherent cells were removed by washing with medium. Cytolysis was performed at $37^{\circ} \mathrm{C}$ for $24 \mathrm{~h}$ in $5 \% \mathrm{CO}_{2}$ incubator. Ratio of number of the effector cells to the tumor cells was 200:1. Reagents were added to the cell suspension with each dose. All of reagents were dissolved in the medium.

observed between the cytolytic activities of two groups of WAM025-activated phagocytes in either presence or absence of the lymphocytes, suggesting that the lymphocytes in PECs obtained from mice administered with WAM025 did not participate in cytolysis of the tumor cells. Fig. 3 demonstrates the relationship between cytolytic effect and number of peritoneal phagocytes in mice administered with WAM025 in a dose of $150 \mathrm{mg} / \mathrm{kg} / \mathrm{d}, 5$ and 10 times. All findings given in Figs. 2 and 3 indicate that the cytolytic effect augmentated by the administration of WAM025 depends on number of the activated phagocytic cells.

Influence of Phagocytic Inhibitors and Active Oxygen Scavengers on Cytolytic Effect of WAM025-Activated Phagocytes

Table I shows the inhibitory effect of each reagent on the in vitro cytolysis by peritoneal phagocytes obtained from mice administered with WAM025 in a dose of $150 \mathrm{mg} / \mathrm{kg} / \mathrm{d}, 10$ times. Colchicine and cytochalasin B, both of which were shown to be the inhibitors of phagocytosis, repressed the cytolytic effect of WAM025-activated phagocytes. On the other hand, cytochrome $\mathrm{C}$ appeared to display a strong inhibitory effect to the cytolysis of WAM025activated phagocytes. The inhibitory effects of superoxide dismutase and catalase were considerably low in comparison with the inhibitors mentioned above.
Chemiluminescence Response of Peritoneal Phagocytes Obtained from WAM025-Administered Mice by Interaction with MM46 Tumor Cells

Fig. 4 shows the results of a kinetic study of chemiluminescence responses of peritoneal phagocytes in mice administered with WAM025 in a dose of $150 \mathrm{mg} / \mathrm{kg} / \mathrm{d}, 5$ times. It will be pointed out that interaction of MM46 tumor cells with WAM025-activated phagocytes elicit generation of active oxygens, and that a proportional dose-response correlation exists between the amounts of generated active oxygens and number of MM46 tumor cells added.

Generation of Active Oxygens from WAM025-Activated Phagocytes by Contacting to MM46 Tumor Cells

Fig. 5 depicts the chemiluminescence responses of peritoneal phagocytes obtained from mice administered with WAM025 in a dose of 150 $\mathrm{mg} / \mathrm{kg} / \mathrm{d}, 5$ and 10 times. Fig. $5 \mathrm{~A}$ indicates the results of time-course study of active oxygen generation in peritoneal phagocytes, each $1 \times 10^{6}$ cells, and Fig. 5B shows the amounts of generated active oxygens in terms of total peritoneal phagocytic cells per mouse. As can be pointed out, increment of the amounts of generated active oxygens from a fixed number of WAM025-activated phagocytes, $1 \times 10^{6}$ cells, was about 4.2 folds. In term of the amounts of generated active oxygens per mouse, however, increase of the values was quite large, 16 and 20 folds, propor- 
tional to the frequencies of in vitro administration of WAM025, 5 and 10 times, respectively.

Effect of Phagocytic Inhibitors and Active Oxygen Scavengers in Chemiluminescence Response of WAM025-Activated Phagocytes

Table II shows the inhibitory effect of various reagents to the chemiluminescence response of peritoneal phagocytes in mice administered with WAM025 in a dose of $150 \mathrm{mg} / \mathrm{kg} / \mathrm{d}, 10$ times. Colchicine and cytochalasin $\mathrm{B}$ repressed strongly the chemiluminescence response of WAM025activated phagocytes, and among scavengers used in the present study, cytochrome $\mathrm{C}$ was found to be the most effective one.

\section{DISCUSSION}

Numerous papers have been published on the importance of phagocytes in host-defense mechanism of mammals against a variety of parasites $^{5-7)}$ and neoplasms, ${ }^{8-10)}$ although the killing mechanism of tumor cells by phagocytes has not yet been fully understood in the present

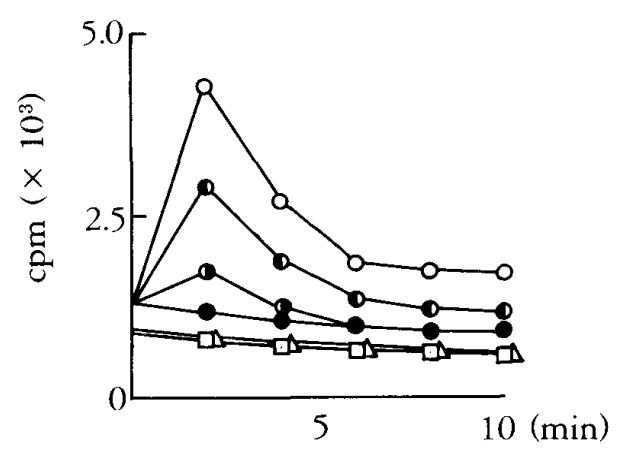

FIG. 4. Chemiluminescence Response of Peritoneal Phagocytes in Mice Administered with Acidic Mannan, WAM025, by MM46 Tumor Cells

The mice were administered i.p. with the mannan for $5 \mathrm{~d}$. Chemiluminescence responses were determined on day 6.

$\square-\square$ : cells free, $\triangle-\triangle$ : tumor cells only, $4 \times$ $10^{6}$, - 0 : Untreated phagocytes, $3 \times 10^{6}$, plus MM46 tumor cells, $4 \times 10^{6}, 0-1:$ WAM025treated phagocytes, $3 \times 10^{6}$, plus MM46 tumor cells, $1 \times 10^{6}, \mathbf{0}-\mathbf{0}:$ WAM025-treated phagocytes, $3 \times 10^{6}$, plus MM46 tumor cells, $2 \times$ $10^{6}, 0-0:$ WAM025-treated phagocytes, $3 \times$ $10^{6}$, plus MM46 tumor cells, $4 \times 10^{6}$. stage. In this paper, we conducted a study that a immunopotentiating polysaccharide, WAM025, increased number of phagocytes and that it induced the increase of cytolytic activity of phagocytes to tumor cell, MM46.

It is well-known that phagocytes such as macrophages and PMNs are able to generate active oxygens, and that increase of the amounts of active oxygens could be observed after ingestion of various microbial cells such as Escherichia coli ${ }^{11)}$ and cell wall components such as zymosan. ${ }^{12)}$ It has also been demonstrated that generation of active oxygens could occur by the action of membrane-stimulating agent such as PMA. ${ }^{10)}$ However, Hafeman et al. ${ }^{13)}$ reported that PMNs did not generate $\mathrm{O}_{2}^{-}$in the presence of tumor cells alone, unless the presence of antibody. In order to determine whether the polysaccharide stimulate generation of active oxygens in the phagocytes, an assay of the amounts of active oxygens was conducted for the WAM025-activated phagocytes (Figs. 4 and 5). The results of this assay clearly indicated that the amounts of
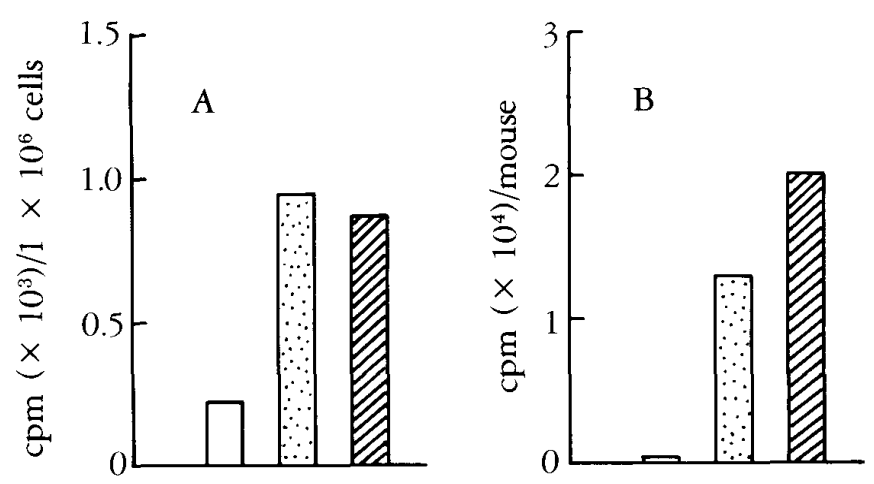

FIG. 5. Kinetics of Chemiluminescence Response of Peritoneal Phagocytes in Mice Administered with Acidic Mannan, WAM025, by MM46 Tumor Cells

The mice were administered i.p. with the mannan for $5^{a)}$ and $10^{b)} d$. Chemiluminescence responses were determined on day 6 and 11.

$\square$ : Untreated phagocytes, plus MM46 tumor cells, $4 \times 10^{6}$, : WAM025-treated phagocytes a) plus MM46 tumor cells, $4 \times 10^{6}$, $\square$ : WAM025-treated phagocytes b) plus MM46 tumor cells, $4 \times 10^{6}$. 
TABLE II. Inhibition of Chemiluminescence Response of Peritoneal Phagocytes in Mice Administered with Acidic Mannan, WAM025

\begin{tabular}{lcc}
\hline \hline \multicolumn{1}{c}{ Reagent } & Concentration & Inhibition (\%) \\
\hline Colchicine & $0.6 \mathrm{mM}$ & 73 \\
Cytochalasin B & $13 \mu \mathrm{M}$ & 74 \\
Cytochrome C & $65 \mu \mathrm{M}$ & 61 \\
Cytochrome C & $130 \mu \mathrm{M}$ & 77 \\
Superoxide dismutase & $150 \mathrm{U} / \mathrm{ml}$ & 34 \\
Superoxide dismutase & $300 \mathrm{U} / \mathrm{ml}$ & 58 \\
Catalase & $150 \mathrm{U} / \mathrm{ml}$ & 44 \\
Catalase & $300 \mathrm{U} / \mathrm{ml}$ & 61 \\
\hline
\end{tabular}

PECs were collected on day 6. Nonadherent cells were removed by washing with medium. Chemiluminescence responses were measured in the presence of PMA (10 $\mathrm{ng} / 10 \mu$ ldimethyl sulfoxide) and each reagent for 10 min. Cytochalasin $B$ was dissolved in dimethyl sulfoxide and others were dissolved in KRPB, pH 7.2.

generated active oxygens in WAM025-activated phagocytes were higher than those detected in the phagocytes of nontreated mice. There has been published a few papers stating that colchicine inhibits the functions of PMNs in vitro: adhesion, ${ }^{14)}$ lysosomal degranulation, ${ }^{14)}$ metabolic burst during phagocytosis, ${ }^{3)}$ and generation of $\mathrm{H}_{2} \mathrm{O}_{2} \cdot{ }^{3)}$ Furthermore, cytochalasin $\mathrm{B}$ inhibits phagocytic function of macrophages, ${ }^{15)}$ although it elevates $\mathrm{O}_{2}^{-}$production ${ }^{3)}$ and cytotoxic activity to target cells. ${ }^{15)}$ As shown in Tables I and II, colchicine and cytochalasin $\mathrm{B}$ inhibited both cytotoxic and active oxygen-generating effects of phagocytes in WAM025-treated mice. Nathan et al. ${ }^{4)}$ reported that macrophages and PMNs treated with BCG and thioglycollate could not lyse tumor cells, but exhibited a marked cytolytic effect in the presence of PMA. Because this function was repressed by the addition of catalase, these workers postulated that $\mathrm{H}_{2} \mathrm{O}_{2}$ corresponded to one of the cytolytic factors. Tsunawaki et al. ${ }^{16)}$ demonstrated that cytolytic effect of PMNs received a strong inhibition in the presence of PMA, but antibody- and lectin-dependent cytolytic functions of PMNs did not undergo repression by the addition of catalase and superoxide dismutase, suggesting that this difference was due to the presence of other cytotoxic factors, such as protease and phospholipase. Clark and Klebanoff ${ }^{17)}$ also presented similar findings in the antibody-dependent cytolysis of PMNs, and postulated that catalase and superoxide dismutase were unable to diffuse into the contacting site between tumor cells and phagocytes. In the present study, the WAM025-activated phagocytes exhibited a strong cytolytic effect to tumor cells without addition of PMA, and a significant decrease of active oxygen in WAM025-activated phagocytes was observed in the presence of superoxide dismutase and catalase. However, it should be emphasized that the decrease of cytolytic effect of WAM025-activated phagocytes with superoxide dismutase and catalase was not proportional to the decrease of active oxygens, suggesting that the superoxide-generating activity does not completely correspond to the cytotoxicity of the phagocytes.

It will therefore be reasonable to state that the active oxygens generated in WAM025-activated phagocytes in cytolysis of MM46 tumor cells participate in the cytolytic effect, although the other cell-injuring factors, lysosomal enzymes, ${ }^{8)}$ myeloperoxidase-hydrogen peroxide-halide system, ${ }^{18)}$ and protease, ${ }^{19)}$ are also assumed to contribute to the cytolytic effect. Because the WAM025-activated phagocytes showed a morphological feature strongly spreading and 
adhering on Petri dish, it is also suggestive that WAM025-activated phagocytes can make contact to a broad area of plasma membrane of the tumor cells, thus evoking alteration of the physiological status of the target cells.

The fact that the amounts of released active oxygens from phagocytes of mice administered with WAM025, 10 times, was not significantly larger than that of mice treated with the same polysaccharide, 5 times, appeared to be inconsistent with difference of extents of cytolytic effects of phagocytes obtained from mice administered with WAM025, 5 and 10 times. This discrepancy seems to indicate that the active oxygen-generating and the cytolytic effects might correspond to PMNs and macrophages in PECs because the phagocytes obtained from mice administered with WAM025, 10 times, contained larger number of macrophages than that obtained from mice administered with WAM025, 5 times.

Acknowledgment This work was supported in part by the grant from the Education, Science and Culture of Japan.

\section{REFERENCES}

1) K. Hashimoto, Y. Okawa, K. Suzuki, Y. Okura, S. Suzuki and M. Suzuki: Antitumor activity of acidic mannan fraction from bakers' yeast, J. Pharm. Dyn., 6, 668-676 (1983).

2) Y. Hashimoto and H. Sudo: Evaluation of cell damage in immune reactions by release of radioactivity from ${ }^{3}$ H-uridine labeled cells, Gann, 62, 139-143 (1971).

3) J. T. Curnutte and B. M. Babior: Effects of anaerobiosis and inhibitors on $\mathrm{O}_{2}^{-}$production by human granulocytes, Blood, 45, 851-861 (1975).

4) C. F. Nathan, S. C. Silverstein, L. H. Brukner and Z. A. Cohn: Extracellular cytolysis by activated macrophages and granulocytes: II. Hydrogen peroxide as a mediator of cytotoxicity, J. Exp. Med., 149, 100-113 (1979).

5) R. J. Mcripley and A. J. Sbarra: Role of the phagocyte in hostparasite interactions, J. Bacteriol., 94, 1417-1424 (1967).

6) G. L. Mandell: Catalase, superoxide dismutase and virulence of Staphylococcus aureus, J. Clin. Invest., 55, $561-566$ (1975).

7) R. B. Johnston, Jr., B. B. Keele, Jr., H. P. Misra, J. E. Lehmeyer, L. S. Webb, R. L. Baehner and K. V. Rajagopalan: The role of superoxide anion generation in phagocytic bactericidal activity: Studies with nor- mal and chronic granulomatous disease leukocytes, $J$. Clin. Invest., 55, 1357-1372 (1975).

8) J. B. Hibbs: Heterocytolysis by macrophages activated by Bacillus Calmette-Guerin: Lysosomal exocytosis into tumor cells, Science, 184, 468-471 (1974).

9) S. Tsunawaki, H. Oshima, D. Mizuno and $\mathbf{M}$. Yamazaki: Induction of polymorphonuclear leukocyte-mediated cytolysis by wheat germ agglutinin and antitumor antibody, Gann, 74, 258-264 (1983).

10) C. F. Nathan, L. H. Brukner, S. C. Silverstein and Z. A. Cohn: Extracellular cytolysis by activated macrophages and granulocytes: I. Pharmacologic triggering of effector cells and the release of hydrogen peroxide, J. Exp. Med., 149, 84-99 (1979).

11) K. Kakinuma, T. Yamaguchi, M. Kaneda, K. Shimada, Y. Tomita and B. Chance: A determination of $\mathrm{H}_{2} \mathrm{O}_{2}$ release by the treatment of human blood polymorphonuclear leukocytes with myristate, J. Biochem. (Tokyo), 86, 87-95 (1979).

12) R. B. Johnston, Jr., C. A. Godzik and Z. A. Cohn: Increased superoxide anion production by immunologically activated and chemically elicited macrophages, J. Exp. Med., 148, $115-127$ (1978).

13) D. G. Hafeman and Z. J. Lucas: Polymorphonuclear leukocyte-mediated, antibody-depending, cellular cytotoxicity against tumor cells: Dependence on oxygen and the respiratory burst: J. Immunol., 123, 55-62 (1979).

14) S. E. Malawista and K. G. Bensch: Human polymorphonuclear leukocytes: Demonstration of microtubules and effect of colchicine, Science, 156, $521-522$ (1967).

15) A. Temple, G. Loewi, P. Davies and A. Howard: Cytotoxicity of immune guinea-pig cells: II. The mechanism of macrophage cytotoxicity, Immunology, 24, 655-669 (1973).

16) S. Tsunawaki, M. Ikenami, D. Mizuno and $M$. Yamazaki: Mechanisms of lectin and antibody-dependent polymorphonuclear leukocyte-mediated cytolysis, Gann, 74, 265-272 (1983).

17) R. A. Clark and S. J. Klebanoff: Studies on the mechanism of antibody-dependent polymorphonuclear leukocyte-mediated cytotoxicity, J. Immunol., 119, 1413-1418 (1977).

18) R. A. Clark and S. Szot: The myeloperoxidasehydrogen peroxide-halide system as effector of neutrophil-mediated tumor cell cytotoxicity, $J$. Immunol., 126, 1295-1301 (1981).

19) D. O. Adams, K. Kao, R. Farb and S. V. Pizzo: Effector mechanisms of cytolytically activated macrophages: II. Serection of a cytolytic factor by activated macrophages and its relationship to secreted neutral proteases, J. Immunol., 124, 293-300 (1980). 